\title{
Serum Level of Beta 2 Microglobulin in End Stage Renal Disease Patients with Pruritus
}

\author{
Haidy S. Rashad', Mona A. Atwa'*, Basma B. Hassan², Roshdy W. \\ Mohammed', Gamal A Tawfik ${ }^{3}$
}

Departments of ${ }^{1}$ Dermatology \& Venereology, ${ }^{2}$ Clinical pathology, and ${ }^{3}$ Internal Medicine \& Nephrology Departments, Faculty of Medicine, Suez Canal University

\begin{abstract}
Background: Etiology of uremic pruritus as a common complication in patients with end stage renal disease (ESRD) is not fully understood. Aim: Our aim was to highlight beta 2 microglobulin $\left(\beta_{2} M\right)$ as a risk factor for uremic pruritus and to assess the diagnostic performance of $\beta_{2} M$ for predicting pruritus in patients with ESRD. We assessed the serum level of $\beta_{2} M$ in hemodialysis patients with pruritus compared to those without pruritus. Subjects and Methods: This study included 17 ESRD patients on hemodialysis with pruritus and 17 ESRD patients on hemodialysis without pruritus. Patients included in this study were subjected to detailed history taking, assessment of pruritus severity using visual analog scale (VAS) in pruritic group, kidney function test and estimation of serum $\beta_{2} M$ levels. Results: The pre-dialysis serum level of $\beta_{2} M$ was significantly higher in pruritic group than in nonpruritic group (2.79 \pm 1.20 and $1.52 \pm 0.66$, respectively, $p=0.002$ ). The post-dialysis serum level of $\beta_{2} M$ was also significantly higher in pruritic group than in nonpruritic group ( $3.44 \pm 1.31$ and $1.89 \pm 0.62$ respectively, $p=0.001$ ). The diagnostic performance of $\beta_{2} \mathrm{M}$ for predicting pruritus in patients with ESRD was good as evidenced by area under the curve (AUC: $81.7, p=0.0001$ ). Best cut off point for predicting pruritus in ESRD was $>2.05$ in predialysis and >2.66 in post-dialysis. Conclusion: Our results showed high serum level of $\beta 2 M$ in ESRD patients with pruritus that may highlight the role of $\beta_{2} M$ in the pathogenesis of this important problem. $\beta_{2} \mathrm{M}$ has good diagnostic performance of for predicting pruritus in patients with ESRD.
\end{abstract}

Key words: Uremic pruritus, middle molecules, beta 2 microglobulin

\section{Introduction}

Pruritus has been well recognized as a common complication in patients with chronic kidney disease ${ }^{(1-4)}$. Uremia is the most common metabolic cause of pruritus. It has been found that $15 \%-49 \%$ of patients with predialysis chronic renal failure and $50 \%-90 \%$ of those on hemodialysis have pru ritus $^{(5)}$. Risk factors include male gender, hi- gh levels of blood urea nitrogen (BUN), elevated calcium, phosphorus and beta 2 microglobulin $(\beta 2 M)$ levels ${ }^{(6)}$. A significant association between itch score and the 3year survival in patients with end stage renal disease (ESRD) has been reported ${ }^{(7)}$. Additionally, a high itch score was significantly associated with death, however, itch score was not shown as an independent prognostic factor ${ }^{(7)}$. Etiology of uremic pru- 
ritus is not fully understood. Some proposed causes include xerosis, decreased transepidermal elimination of pruritogenic factors, hyperparathyroidism, hypercalcemia, hyperphosphatemia, elevated histamine levels, increased dermal mast cell proliferation, uremic sensory neuropathy and middle molecule theory ${ }^{(8-14)}$. The middle molecule hypothesis was proposed by Babb and Scribner in the early 1970s, based on outcomes and quality of life with peritoneal dialysis similar to hemodialysis in spite of marked differences in adequacy of small molecule removal. ${ }^{(15)}$ They therefore proposed that larger middle molecules (ranging in size between the small molecules and the large proteins) played a pathophysiologic role. However, it was impossible to indicate real culprits, as analytical techniques at that time were unrefined. When it became apparent that a specific amyloid, containing large amounts of $\beta_{2} \mathrm{M}$ developed in dialysis patients after many years of renal replacement therapy ${ }^{(16)}$, interest in the middle molecules was finally regained.

In a review of uremic solutes, the European Uremic Toxin Work Group (EUTox) identified 22 known middle molecules ${ }^{(17)}$. The middle molecule theory suggests the existence of yet unidentified prurito-genic substances that accumulate in the dialysis patients, because they are poorly dialyzable because of their molecular size. Pruritus typically resolves after transplantation, with the restoration of renal function ${ }^{(15)}$. $\beta_{2} \mathrm{M}$ is a component of major histocompitability complex (MHC) class I molecules, which are present on all nucleated cells ${ }^{(18)}$. It is found at low levels in the serum and urine of normal individuals. $\beta 2 \mathrm{M}$ concentrations are increased in inflammatory diseases, some viral diseases, renal dysfunction, and autoimmune diseases. In patients on long term hemodialysis, it can aggregate into amyloid fibers that deposit in joint spaces, a disease known as dialysis related amyloidosis $^{(19)}$. $\beta 2 \mathrm{M}$ has become a frequently used marker for the dialytic removal of middle molecules ${ }^{(20)}$. The study was conducted to highlight the possible role of $\beta_{2} \mathrm{M}$ in the pathogenesis of pruritus associated with ESRD, and to assess the diagnostic performance of $\beta 2 \mathrm{M}$ for predicting pruritus in patients with ESRD.

\section{Subjects and Methods}

\section{Study setting}

This case-control study assessed the serum concentration of $\beta_{2} \mathrm{M}$ in hemodialysis patients with pruritus compared to those without pruritus. The study was conducted in the dermatology clinic at Suez Canal University Hospital, Ismailia, Egypt. The local Institutional Review Board approved it.

\section{Subjects}

Seventeen ESRD patients on hemodialysis with pruritus, and 17 ESRD patients on hemodialysis without pruritus were enrolled in this study. Patients were consented to participate after having received full information on the setup and the purpose of the study. The criteria for diagnosis of uremic pruritus included; pruritus that appeared shortly before the onset of dialysis, or at any time, without evidence of any other active disease that could explain the pruritus, more than or equal to three episodes of itch during a period of $<2$ weeks, with the symptom appearing a few times a day, lasting at least few minutes, and troubling the patient, appearance of an itch in a regular pattern during a period of 6 months, but less frequently than listed above. Patients with other systemic causes of pruritus such as cholestatic liver disease and Hepatitis $C$ virus positive patients, and patients with any itchy skin conditions were excluded. A careful history concerned general medical history was taken from each patient. Data regarding onset, dura- 
tion, frequency of pruritus, associated symptoms, antipruritic medications, and the impact of pruritus on sleep and daily activities were obtained from patients with pruritus. Verbal descriptor scale of itch sensation and affective dimension was used for assessment of pruritus. The following 6 words were used to describe the sensation; tickling, stinging, crawling likes ants, stabbing, pinching and burning. Another set of four words was used to characterize the affective dimension of the itch: bothersome, annoying, unbearable, and/or worrisome. Each descriptor could be ranked on an intensity scale of $0=$ none, $1=$ mild, $2=$ moderate, and $3=$ severe. For the 6 parameters describing sensation an index of sensation was calculated as the sum of all parameters divided by the maximum possible number 18 . For the four affective parameters, an index of affect was similarly calculated. The questions of the patients regarding sensory and affective dimensions referred to pruritus during the last halfyear. The severity of pruritus was assessed by visual analogue scale (VAS) for 4 different temporal states; at present, i.e. at the time when the patient is being examined, at the time of the worst pruritus, at the time when the condition was in the best state, and at the time of the strongest itch after a mosquito bite. A VAS was constructed consisting of a $10 \mathrm{~cm}$ line anchored at one end by a label "no itch" and at the opposite end by a label "very strong itch, as bad as could possibly be". The subject is asked to mark the intensity of the itch in the aforementioned situations.

\section{Laboratory assessment}

Venous blood samples (5-10 $\mathrm{mL}$ ) were taken in a pyrogen free vacutainer tubes under sterile conditions from patients before and after dialysis session. Serum was obtained from freshly drawn, rapidly centri- fuged sample and quickly frozen at $-20^{\circ} \mathrm{C}$ until processed. Estimation of serum urea and creatinine levels was done using COBAS 501 chemistry autoanalyzer (Roche Diagnostics, USA). Beta 2 microglobulin level was measured in all patients before and after dialysis session by enzyme-linked immune-sorbent assay (ELISA) commercial kit ( $\beta_{2} M$ Enzyme Immunoassay kit, DRG International, Inc., USA).

\section{Statistical analysis}

Data were analyzed using the Statistical Package for Social Sciences (SPSS) version 17.0 software (SPSS Inc., Chicago, Illinois, USA). Kolmogorov-Smirnov test was carried out for collected data and for each variable to determine whether the data were parametric or non-parametric. For parametric data, Students $t$ test was used for test of difference for quantitative variables between 2 groups. For non-parametric data, Mann- Whitney test was used to compare the 2 independent group means. Chi square test was used as a test of significance for categorical variables. In all statistical assessments performed, the level of significance was recognized at $95 \%$ level of confidence $(p<0.05)$ to indicate the statistical significance between the studied variables.

\section{Results}

This study included 17 ESRD patients on hemodialysis with pruritus (pruritic group) and 17 ESRD patients on hemodialysis without pruritus (nonpruritic group). The mean age for patients with and without pruritus was $41.6 \pm 10.9$ and $37.0 \pm 7.8$ years respectively $(p=0.218)$. The duration of dialysis ranged from 1-7 years in nonpruritic group (mean 3.59 \pm 1.70 ) and 3-16 years in pruritic group (mean 10.53 $\pm 3.71, p<0.001$ ) 
Table 1: Features of pruritus and its impact on hemodialysis patients with pruritus

\begin{tabular}{|c|c|}
\hline Effects of Pruritus & \begin{tabular}{|l|} 
Pruritic \\
group $(n=17)$
\end{tabular} \\
\hline $\begin{array}{l}\text { Onset } \\
\text { Before dialysis } \\
\text { After dialysis }\end{array}$ & $\begin{array}{l}0 \\
17(100 \%)\end{array}$ \\
\hline $\begin{array}{l}\text { Course } \\
\text { Progressive } \\
\text { Stationary } \\
\text { Intermittent }\end{array}$ & $\begin{array}{l}11(64.7 \%) \\
4(23.5 \%) \\
2(11.8 \%)\end{array}$ \\
\hline $\begin{array}{l}\text { Duration of pruritus (month) } \\
\text { Mean } \pm \text { SD } \\
\text { (Range) }\end{array}$ & $\begin{array}{l}5.71 \pm 13.85 \\
(0-48)\end{array}$ \\
\hline $\begin{array}{l}\text { Site } \\
\text { Specific sites } \\
\text { All over the body }\end{array}$ & $\begin{array}{l}5(29.4 \%) \\
12(70.6 \%)\end{array}$ \\
\hline $\begin{array}{l}\text { Timing } \\
\text { No specific time } \\
\text { After dialysis } \\
\text { At night } \\
\text { After dialysis \& at night }\end{array}$ & $\begin{array}{l}7(41.2 \%) \\
6(35.3 \%) \\
2(11.8 \%) \\
2(11.8 \%)\end{array}$ \\
\hline $\begin{array}{l}\text { Accompanying symptoms } \\
\text { Yes } \\
\text { No }\end{array}$ & $\begin{array}{l}7(41.2 \%) \\
10(58.8 \%)\end{array}$ \\
\hline $\begin{array}{l}\text { Circadian changes in appear- } \\
\text { ance \& pattern } \\
\text { Yes } \\
\text { No }\end{array}$ & $\begin{array}{l}10(58.8 \%) \\
7(41.2 \%)\end{array}$ \\
\hline $\begin{array}{l}\text { Effect of current anti-pruritic } \\
\text { drugs } \\
\text { No drugs } \\
\text { No effect } \\
\text { Short-term effect }\end{array}$ & $\begin{array}{l}2(11.8 \%) \\
12(70.6 \%) \\
3(17.6 \%)\end{array}$ \\
\hline $\begin{array}{l}\text { Effect on sleep } \\
\text { No effect } \\
\text { Difficulty in falling asleep } \\
\text { Disturbance of sleep } \\
\text { Requirement of } \\
\text { soporifies }\end{array}$ & $\begin{array}{l}3(17.6 \%) \\
8(47.1 \%) \\
5(29.4 \%) \\
1(5.9 \%)\end{array}$ \\
\hline $\begin{array}{l}\text { Effect on daily activities \& } \\
\text { habits } \\
\text { No } \\
\text { Yes }\end{array}$ & $\begin{array}{l}17(100 \%) \\
0\end{array}$ \\
\hline $\begin{array}{l}\text { Effect on mood, behavior \& } \\
\text { ability to concentrate } \\
\text { No } \\
\text { Yes }\end{array}$ & $\begin{array}{l}3(17.6 \%) \\
14(82.4 \%)\end{array}$ \\
\hline
\end{tabular}

All patients in the pruritic group developed pruritus after they started hemodialysis. Table 1 showed the features and impact of pruritus in the pruritic group. VAS score ranged from 3-10 with mean of 7.06 \pm 2.19 in patients with pruritus. The majority of patients [11 (64.7\%)] had severe pruritus (VAS $\geq 7$ ), while 5 (29.4\%) patients had moderate pruritus (VAS $=4-6$ ) and only one patient (5.9\%) had mild pruritus (VAS $\leq 3$ ). Serum creatinine was significantly higher in pruritic group compared to nonpruritic group $(9.23 \pm 2.32 \mathrm{mg} / \mathrm{dl}$ versus $6.92 \pm 0.82$ $\mathrm{mg} / \mathrm{dl}, p=0.001)$. Patients in the pruritic group also had significantly higher serum urea level compared to patients in the nonpruritic group $(172.2 \pm 40.6 \mathrm{mg} / \mathrm{dl} v \mathrm{v}$. $114.1 \pm 18.8 \mathrm{mg} / \mathrm{dl}, \mathrm{p}=0.001)$. Pre-dialysis assessment of serum $\beta_{2} M G$ showed that mean serum level of $\beta 2 M G$ was significantly higher in pruritic group compared to nonpruritic group $(2.79 \pm 1.20 \mathrm{mcg} / \mathrm{ml}$ versus $1.52 \pm 0.66 \mathrm{mcg} / \mathrm{ml}, \mathrm{p}=0.002)$. Post-dialysis level of $\beta 2 M G$ was also significantly higher in the pruritic group. Our results also showed that the post-dialysis level of $\beta 2 M C$ was significantly higher in both pruritic and nonpruritic groups compared to predialysis level (Table 2).

Mann-Whitney test and Wilcoxon sign rank test showed significant higher level of $\beta_{2} \mathrm{MG}$ in pruritic group compared to nonpruritic group in both pre-dialysis and post- dialysis assessment. Post-dialysis level of $\beta_{2} \mathrm{MG}$ was also higher than pre-dialysis level in both groups. The diagnostic performance of $\beta_{2} M G$ for predicting pruritus in patients with ESRD was good as evidenced by area under the curve (AUC) of 81.7 and this was statistically significant. Best cut off point for predicting pruritus in ESRD was $>2.05$ in pre dialysis and $>2.66$ in post dialysis (table 3 ). 
Table 2: Serum concentration of $\beta 2$-microglobulin in pruritic \& non-pruritic patients

\begin{tabular}{|l|l|c|c|c|}
\hline \multicolumn{2}{|c|}{} & $\begin{array}{c}\text { Non-Pruritic group } \\
(n=17)\end{array}$ & $\begin{array}{c}\text { Pruritic group } \\
(n=17)\end{array}$ & $p$-value ${ }^{\mathrm{a}}$ \\
\hline$\beta 2-$ & Pre-dialysis & $1.52 \pm 0.66(0.84-3.5)$ & $2.79 \pm 1.20(099-4.0)$ & $0.002^{*}$ \\
microglobulin & Post-dialysis & $1.89 \pm 0.62(1.23-3.48)$ & $3.44 \pm 1.31(1.25-5.6)$ & $0.001^{*}$ \\
$(\mu \mathrm{g} / \mathrm{ml})$ & $p^{2}$ & $0.003^{*}$ & $0.002^{*}$ & \\
& Avalue $^{\mathrm{b}}$ & $1.71 \pm 0.61(1.06-3.52)$ & $3.12 \pm 1.21(1.18-5.06)$ & $0.001^{*}$ \\
\hline
\end{tabular}

${ }^{\mathrm{a}}=$ Mann-Whitney test; ${ }^{\mathrm{b}}$ Wilcoxon sign rank test; ${ }^{*}=$ Statistically significant at $p<0.05$

Table 3: Diagnostic performance of $\beta 2$-microglobulin for predicting pruritus in ESRD

\begin{tabular}{|l|ccc|}
\hline & $\begin{array}{c}\text { Pre-dialysis } \beta 2 \mathrm{M} \\
(\mu \mathrm{g} / \mathrm{ml})\end{array}$ & $\begin{array}{c}\text { Post-dialysis } \beta 2 \mathrm{M} \\
(\mu \mathrm{g} / \mathrm{ml})\end{array}$ & $\begin{array}{c}\text { Average } \beta 2 \mathrm{M} \\
(\mu \mathrm{g} / \mathrm{ml})\end{array}$ \\
\hline Best cut-off value & $>2.05$ & $>2.66$ & $>2.35$ \\
AUC \% $(p$ value $)$ & $80.3\left(0.0002^{*}\right)$ & $81.8\left(0.0001^{*}\right)$ & $81.7\left(0.0001^{*}\right)$ \\
Sensitivity \% $(95 \% \mathrm{Cl})$ & $70.6(44.0-89.7)$ & $76.47(50.1-93.2)$ & $76.47(50.1-93.2)$ \\
Specificity \% $(95 \% \mathrm{Cl})$ & $88.2(63.6-98.5)$ & $94.12(71.3-99.9)$ & $94.12(71.3-99.9)$ \\
PPV\% $(95 \% \mathrm{Cl})$ & $85.7(57.2-98.2)$ & $92.9(66.1-99.8)$ & $92.9(66.1-99.8)$ \\
NPV\% $(95 \% \mathrm{Cl})$ & $75.0(50.2-91.7)$ & $80.0(56.3-94)$ & $80.0(56.3-94.3)$ \\
\hline
\end{tabular}

PPV= Positive predictive value; NPV= Negative predictive value; Best cut off point for predicting pruritus in ESRD was $>2.05$ in pre dialysis and $>2.66$ in post dialysis. ${ }^{*}=$ Statistically significant at $p<0.05$.

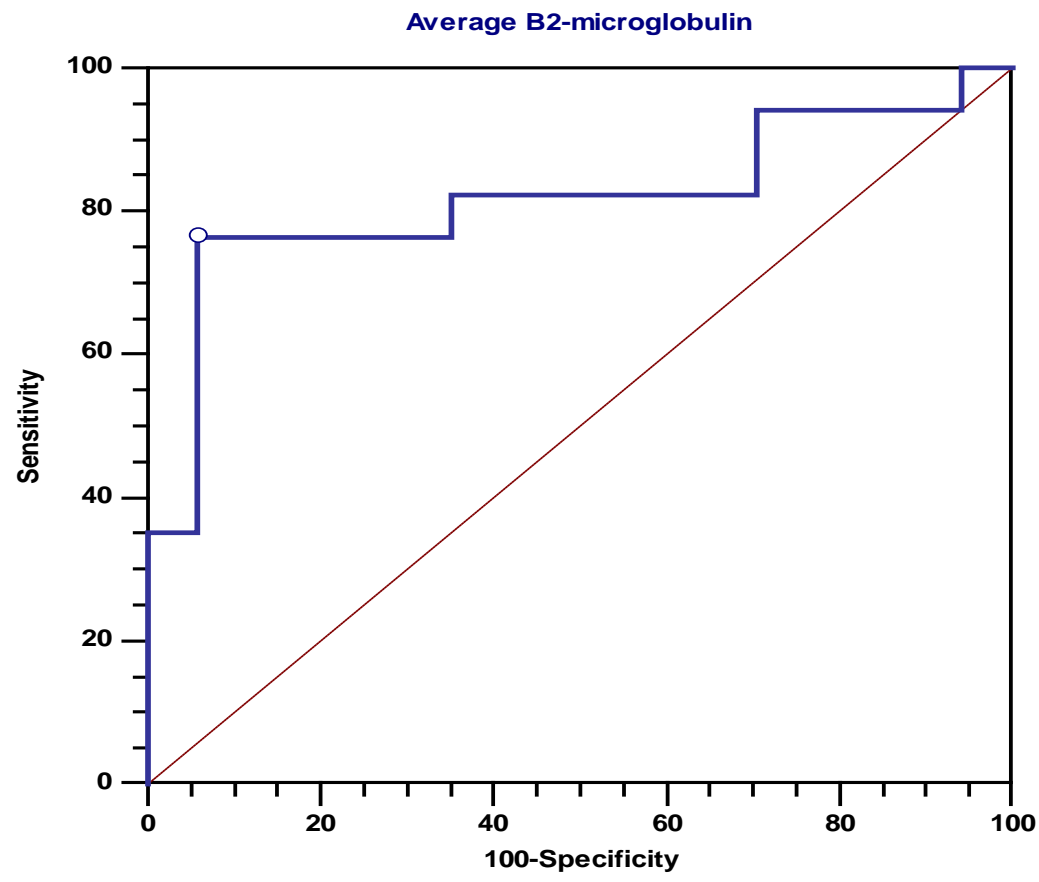

Figure 1: ROC curve for cut-off values of average $\beta 2$-microglobulin

\section{Discussion}

Pruritus affects $50 \%$ to $90 \%$ of patients with $\operatorname{ESRD}^{(2,4,5)}$. The increase in the incidence of pruritus could be due to the prolonged survival of patients with end stage renal failure. The wide variation may reflect the fact that pruritus is a subjective sensation and 
can be influenced by psychological factors. The frequency of pruritus has increased dramatically with the advent of hemodialy$\mathrm{sis}^{(21)}$. The pathogenesis of pruritus in hemodialysis patients appears to be multifactorial. However, the precise underlying mechanism remains elusive. Retention of middle molecules (molecular weight range 300 - 12000 Daltons) is thought to cause pruritic symptoms in CRF patients. $\beta_{2} M$, advanced glycosylation end products (AGE) and parathyroid hormone (PTH) are middle molecules that have been evaluated but their role is still uncertain ${ }^{(22)}$. In this study, $\beta_{2} \mathrm{M}$ level was measured as the prototype of middle molecules and our results showed statistically significant higher level of $\beta_{2} \mathrm{M}$ among patients with pruritus in both pre-dialysis and post-dialysis assessments. The level of $\beta_{2} \mathrm{M}$ was higher in postdialysis than in pre-dialysis assessment in both groups. Previous studies showed that a high level of $\beta_{2} M$ is independently associated with the development of severe uremic pruritus ${ }^{(3,9,12)}$. In agreement with other studies $^{(2,5,6)}$. We cannot find association between severity of pruritus and level of $\beta_{2} \mathrm{M}$. Our results showed a longer duration of dialysis in pruritic group compared to nonpruritic group. The longer duration of dialysis was correlated with significant risk factors such as the high levels of $\beta_{2} M$ and BUN, which may explain the increased incidence of pruritus. Some studies revealed that the $\beta_{2} M$ content in skin tissue increases with the duration of dialysis, but there is no evidence for a direct cause and effect relationship between $\beta_{2} \mathrm{M}$ and pruritus $^{(2,5,6,9,11,12)}$.

Uremic pruritus is independent of gender, age, race, or etiology of kidney failure; however, it has been associated with the degree of renal insufficiency (urine output of $<500 \mathrm{~mL})^{(2)}$. In agreement with our results, previous studies showed that the mean level of blood urea and creatinine were significantly higher in patients with severe pruritus ${ }^{(11,23)}$. On the other hand, absence of relationships between pruritus and many common biochemical results as well as patients' age, hemodialysis duration and time on hemodialysis treatment was reported in several studies ${ }^{(12,13)}$.

To the best of our knowledge, no previous studies assess the diagnostic performance of $\beta_{2} \mathrm{M}$ for predicting pruritus in patients with ESRD. Our results showed that the diagnostic performance of $\beta_{2} \mathrm{M}$ for predicting pruritus in patients with ESRD was good as evidenced by AUC of 81.7 and this was statistically significant. Best cut off point for predicting pruritus in ESRD was $>2.05$ in pre-dialysis and $>2.66$ in postdialysis. Our results suggest that $\beta 2 \mathrm{M}$ may help in prediction of pruritus in patients with ESRD.

\section{Conclusion}

Our results showed high serum level of $\beta_{2} M$ in ESRD patients with pruritus that may highlight the role of $\beta_{2} \mathrm{M}$ in the pathogenesis of this important problem. The exploration of the underlying pathogenic mechanisms of pruritus may show promise for future treatment modalities. $\beta 2 \mathrm{M}$ may also help in prediction of pruritus in patients with ESRD.

\section{References}

1. Gilchrest BA, Stern RS, Steinman TI, Brown RS, Arndt KA, Anderson WW. Clinical features of pruritus among patients undergoing maintenance hemodialysis. Arch Dermatol 1982; 118 (3): 154-156.

2. Bencini PL, Montagnino G, Citterio A, Graziani G, Crosti C,Ponticelli C. Cutaneous abnormalities in uremic patients. Nephron $1985 ; 40$ (3):316-321.

3. Ponticelli C, Bencini PL. Pruritus in dialysis patients: a neglected problem. Nephrol Dial Transplant 1995 ; 10 (12): 2174- 2176. 
4. Schwartz IF, laina A. Uraemic pruritus. Nephrol Dial transplant $1999 ; 14(4): 834$ 839.

5. Ponticelli C, Bencini PL. Uremic pruritus: a review. Nephron $1992 ; 60$ (1): 1-5.

6. Narita I, Alchi B, Omori K, Sato F, Ajiro J, Saga D, Kondo D, Skatsume $M$, Maruyama S, Kazama JJ, Akazawa K, Gejyo F. Etiology and prognostic significance of severe uremic pruritus in chronic hemodialysis patients. Kidney Int 2006; 69 (9): 1626-1632.

7. Carmichael AJ, McHugh MI, Martin AM. Renal itch as an indicator of poor outcome. Lancet . 1991; 337 (8751): 1225-1226

8. Cawley, IP, Hoch-Ligeti, C, Bond, GM. The eccrine sweat glands of patients in uremia. Arch Dermatol 1961; 84:889-897.

9. Massry SG, Popovtzer MM, Coburn JW, Makoff DL, Maxwell MH, Kleeman CR. Intractable pruritus as a manifestation of secondary hyperparathyroidism in uremia. Disappearance of itching after subtotal parathyroidectomy. N Engl J Med 1968; 279 (13): $697-700$.

10. Parfitt AM, Massry SG, Winfield AC, Depalma JR, Gordon A. Disordered calcium and phosphorus metabolism during maintenance hemodialysis. Correlation of clinical, roentgenographic and biochemical changes. Am J Med 1971; 51 (3): 319 - 330.

11. Blachley JD, Blankenship DM, Menter A, Parker TF 3rd, Knochel JP. Uremic prutitus: Skin divalent ion content and response to ultraviolet phototherapy. Am J Kidney Dis 1985; 5 (5): 237-241.

12. Hiroshige $K$, Kabashima $N$, Takasugi $M$, Kuroiwa A. Optimal dialysis improves uremic pruritis. Am J Kidney Dis 1995; 25 (3): $413-419$.

13. De Marchi S, Cecchin E, Villalta D, Sepiacci G, Santini G, Bartoli E. Relief of pruritis and decreases in plasma histamine concentrations during erythropoietin therapy in patients with uremia. N Engl J Med 1992 ; 326 (15) : 969 - 974.

14. Kessler M, Moneret-Vautrin DA, Cao-Huu T, Mariot A, Chanliau J. Dialysis pruritis and sensitization. Nephron 1992; 60 (2): 241.

15. Babb AL, Ahmad S, Bergström J, Scribner $\mathrm{BH}$. The middle molecule hypothesis in perspective. Am J Kidney Dis.1981; 1 (1): 4650.

16. Gejyo F, Odani S, Yamada T, Honma N, Saito $\mathrm{H}$, Suzuki $\mathrm{Y}$, Nakagawa $\mathrm{Y}$, Kobayashi $\mathrm{H}$, Maruyama $Y$, Hirasawa $Y$, et al. Beta 2microglobulin: a new form of amyloid protein associated with chronic hemodialysis. Kidney Int. 1986; 30 (3): 385-390.

17. Vanholder R, De Smet R, Glorieux G, Argilés A, Baurmeister $U$, Brunet $P$, Clark W, Cohen G, De Deyn PP, Deppisch R, Descamps-Latscha $B$, Henle $T$, Jörres $A$, Lemke HD, Massy ZA, Passlick-Deetjen J, Rodriguez $M$, Stegmayr $B$, Stenvinkel $P$, Tetta C, Wanner C, Zidek W; European Uremic Toxin Work Group (EUTox).Review on uremic toxins: classification, concentration, and interindividual variability. Kidney Int. 2003; 63 (5): 1934-1943.

18. Güssow D, Rein R, Ginjaar I, Hochstenbach F, Seemann G, Kottman A, Ploegh HL. The human beta 2 microglobulin gene. Primary structure and definition of the transcriptional unit. J Immunol 1987139 (9): 3132-8.

19. Niwa $T$, Sato $M$, Katsuzaki $T$, Tomoo $T$, Miyazaki T, Tatemichi N, Takei $\mathrm{Y}$, Kondo T. Amyloid beta 2-microglobulin is modified with $\mathrm{N}$ epsilon-(carboxymethyl)-lysine in dialysis related amyloidosis. Kidney Int. 1996;50 (4): 1303-1309.

20. Ward RA, Schmidt B, Hullin J, Hillebrand GF, Samtleben W. A comparison of on-line hemodiafiltration and high-flux hemodialysis: a prospective clinical study. J Am Soc Nephrol 2000 ; 11 (12): 2344 - 2350.

21. Sato S. Iron deficiencies: structural and microchemical changes in hair, nails, and skin. Semin Dermatol 1991; 10 (4): 313-319.

22. Mettang T, Fritz P, Weber J, Machleidt C, Hübel $E$, Kuhlmann U. Uremic pruritus in patients on hemodialysis or continuous ambulatory peritoneal dialysis (CAPD). The role of plasma histamine and skin mast cells. Clin Nephrol 1990; 34 (3): 136-141

23. Momose A, Kudo S, Sato M, Saito H, Nagai K, Katabira Y, Funyu T. Calcium ions are abnormally distributed in the skin of haemodialysis patients with uremic pruritus. Nephrol Dial Transplant 2004; 19 (8): 20612066 . 
